\title{
Analysis of the Water Quality Deterioration in secondary water-supply systems
}

\author{
Cuihua $\mathrm{Li}^{1, \mathrm{a}}$ and Guanye Wang ${ }^{2, \mathrm{~b}}$ \\ ${ }^{1}$ School of civil engineering and architecture Wuhan University of Technology, Wuhan, China \\ ${ }^{2}$ CCCC Second Harbor Consultants Co., Ltd., Wuhan, China \\ a496884406@qq.com, b8063769@qq.com
}

\begin{abstract}
Keywords: Water supply network ; Secondary water supply system; Water quality; Operational maintenance; Re-construct.
\end{abstract}

\begin{abstract}
Based on the analyses of quality of treated water. texture and useful Life of water supply pipe, operational maintenance of network and secondary water supply system, measures such as improving the stability water quality, designedly re-constructing the existing water network and secondary water supply system, strengthening the maintenance were proposed.
\end{abstract}

\section{Introduction}

Drinking water is closely related to people's health. With the development of the industrialization and the improvement of people's living standard, source water pollution has attracted a worldwide attention and higher standard for water quality is needed. After rigorous treatment process at water plant, the quality indexes of drinking water have met the quality and hygiene standards of the State for drinking water. There exists a dwell time before drinking water reached water user terminal in the pipe network, during which complex physical, chemical and biological changes of water will happen. Naturally, the stability of water quality in pipe network is unsatisfactory.

According to the survey based on "Urban water supply industry technology development plan in 2000 ", only $21 \%$ of surface water plants can ensure the basic stability of the water quality, and $50 \%$ of them have a tendency to corrosion, and $29 \%$ to scaling; $50 \%$ of groundwater water plants can supply drinking water which has a basically stable quality, and 30\% of them have a tendency to corrosion, and $20 \%$ to scaling ${ }^{[1]}$. Compared with treated water, qualified rate of water flow through pipe network and secondary water supply facilities decreased by $20 \%$. Based on analysis of results (average value) concluded from correspondences from 45 domestic cities, some relevant information reports that ${ }^{[2-5]}$ water turbidity, color degree, iron concentration, manganese concentration, total bacteria and coliform group increased by $0.38 \mathrm{NTL}, 0.45 \mathrm{CU}, 0.04 \mathrm{mg} / \mathrm{L}, 0.02 \mathrm{mg} / \mathrm{L}, 18 \mathrm{cfu} / \mathrm{L}$ and 0.4 colonies/L respectively when water flow from treatment plant to pipe network. These data show that urban water supply have existed serious problems such as degradation of water quality in pipe network and serious secondary pollution, which reduced the quality of the residents drinking water and affected the residents health.

\section{Analysis of the pollution in secondary water supply network}

Quality of output water . The stability of water quality refers to chemical stability and biological stability: chemical instability leads to pipeline corrosion, and biological instability results in bacterial population. Biological stability can be explained by saturation index(IL) and stability index(IR). Water quality is stable when $\mathrm{IL}=0$; water have a tendency to scaling when $\mathrm{IL}>0$, and then the carbonate is saturated; carbonate is unsaturated When IL $<0$, and then concentration of corrosive CO2 is excess which means protective carbonate film will failed to form and the inner wall of the pipe will be corroded by water. Water is corrosive when IR $>7$; calcium carbonate scales and corrosive water will not come into being when IR=6 7; calcium carbonate scales will appear when IR $<6$. AOC can indicate the biological stability of water. AOC(Assimilable Organic Carbon) refers to the part of 
organic matter which can be most easily absorbed and assimilated into a part of the bacteria. AOC evaluates the growth potential of bacteria. ${ }^{[6]}$

Impacts of pipes for quality of supply water . Data shows the water quality in pipe networks which use galvanized steel pipe and steel plastic pipe in a southern district is displayed in table 1.

Table 1 . Comparison of water quality between galvanized steel pipe and steel plastic pipe

\begin{tabular}{|l|l|l|}
\hline Parameters & Galvanized steel pipe & Steel plastic pipe \\
\hline Color degree(CU) & 11.8 & 8.1 \\
\hline Turbidity(NTL) & 8.2 & 0.74 \\
\hline Fe(mg/L) & 0.455 & 0.175 \\
\hline Residual chlorine(mg/L) & 0.25 & 0.28 \\
\hline
\end{tabular}

Table 1 shows that, on account of corrosion of galvanized steel pipe, indexes such as turbidity and iron concentration of water exceed the standard. Even the most indexes of water quality have met the quality and hygiene standards of the State for drinking water, color degree, turbidity and iron concentration are still higher than water in steel plastic pipe.

Impacts of dwell time for quality of supply water. Low flow velocity in tube of large diameter and pipes which failed to ring prolong the dwell time of water. Then more biological and chemical reactions occur in pipes and facilities which may worsen the water quality. Water consumption is always very low in low residence community with occupancy rate which is located at the end of branched network. On account of the prolonged dwell time, turbidity may occasionally exceed the standard, residual chlorine also below $0.05 \mathrm{mg} / \mathrm{L}$. These eventually led to the exceeding of microbial indicators.

\section{Impacts of secondary water supply facilities for quality of supply water.}

Unreasonable design. Water's residence time will be too long when volume of storage reservoir or head water tank is designed too large. Since fire demand and domestic water shared the storage reservoir and water tank before 2004, there exist a dead water region which is for fire protection.

Imperfect safeguards. Protective linings of reinforced concrete storage reservoir and water tank are always missing.

Mismanagement of running. Storage reservoir and water tank didn’t get regular cleaning and disinfection. What's more, partial manholes of storage reservoir and water tank are missing or damaged.

Others factors. There are also other factors which may impact water quality, such as irregular construction, incomplete cleaning and disinfection for new laid pipes, changes of hydraulic pressure and flow direction caused by opening and closing valves, sediments, dead water comes from rarely used fire hydrant regorging to the pipe network, external water which may pollute the clean water infiltrating into the pipe network from valves and pipes soaked in water.

In conclusion, chlorinated water has slightly corrosive effects which may increase the color degree, turbidity and iron concentration. Thanks to the low oxygen consumption and residual chlorine, probability of microbes' growth in pipe network is very low. Eligible rates of turbidity, residual chlorine, total bacteria and coliform group declined in different levels when we detect the water quality in secondary water supply. There is also a larger reduction than in pipe network. Corrosive grey cast-iron pipe and galvanized steel pipe cannot guarantee the quality of water in pipe network. The long residence time and improper design or maintenance of secondary water supply facilities may spoil the water quality.

\section{Control measures of water recontamination in secondary water supply}

Improve the quality and stability of treated water. Prevent turbidity from exceeding the standard. In view of some research materials, percentage of removed organics is 27.3 when turbidity is $2.5 \mathrm{NTU}$; 60 percent of organics is removed when turbidity is $1.5 \mathrm{NTU}$; 79.6 percent when turbidity is reduced to $0.1 \mathrm{NTU}$, and then most of the organic matter and pathogenic microorganism have been removed. Due to the reduction of organic content, quantity of organic halogenated hydrocarbon which generated by chlorination are also reduced. On count of water quality stability, 
stabilizing for treated water is needed. Feasible method at present to improve water quality stability is adjusting $\mathrm{pH}$. That means adding stabilizer before water run into pipe network to adjust $\mathrm{pH}$ to7 8.5. Keep AOC, BDOC and permanganate index under ceiling limit value to inhibit the growth and breeding of bacteria is also advocated. ${ }^{[7]}$

Optimize the material of pipe. Appropriate selection for pipe is the key to make sure water is always perfectly clean. Data comes from a survey show that more than $80 \%$ of the pipe material used in urban water supply network are cast-iron pipe. In recent years, ductile cast iron pipes is gradually replacing grey iron pipe. Ductile cast iron pipes account about 50 percent in Tokyo's water supply network; the United States installed 230,000 km yearly in the recent years, and $47.7 \%$ of which are ductile cast iron pipes. These data illustrate that ductile cast iron pipes is the major tubing in urban water supply network.

Consummating the design and construction of secondary water supply facilities. In the aspect of design and construction, water quality safety should be listed as a necessary procedure. Selecting anti-pollution and corrosion-resistant material, finding sustainable solution to prevent fire demand and domestic water from sharing storage reservoir or water tank, disinfecting and flushing water tank regularly and reducing water's dwell time in tank are all effective methods. To avoid water pollution, feeding chlorine or reinforcing gas is recommended when water's dwell time in storage reservoir is more than one day. Relevant administration bylaws and system for urban secondary water supply management should be enacted so that the whole processes of design, acceptance, flushing and disinfection have someone in charge.

Flushing the network. The practice shows that termly flush the water networks can effectively improve water quality, recover capacity of carrying water and inhibit corrosion. Re-suspension of weak adhered settling particulate occurs when velocity and flow direction changed. Flushing can reduce net-accumulation of particulate matters so that turbidity of water are kept under the standard value. Increase the disinfectant dosage during the flushing process can kill the re-suspended microbes. Adding the corrosion inhibitor after flushing which promotes the formation of pipe's inner surface protective film is also recommended. Particularly, the end of pipe network, fire hydrants and drainage valves should be drainage flushed termly.

\section{Conclusions}

Compared with the treated water, qualified rate of water in pipe network and secondary water supply system declined in different degrees. Secondary water supply system has a greater impact on water quality than pipe network. Factors such as quality of treated water, texture and useful Life of water supply pipe, maintenance of network and secondary water supply system can explain such phenomenon. Many method can be used to stabilize water quality. Firstly, values of turbidity and residual chlorine should be controlled to improve the qualified rate and stabilize water quality. Secondly, strengthening the maintenance and scientific control of pipe network and secondary water supply system are also helpful. At last, designedly re-construct the existing water network and secondary water supply system can eliminate hidden troubles of water quality.

\section{Acknowledgements}

This work was supported by "the Fundamental Research Funds for the Central Universities(WUT: 2014-IV-124)".

\section{References}

[1] Dj.M. Maric, P.F. Meier and S.K. Estreicher: Mater. Sci. Forum Vol. 83-87 (1992), p. 119

[1] Technology Development Plans for 2010 and Vision for 2020 of Urban Water Supply Industry. Beijing: China Architecture \& Building Press, 2005. 
[2] Ren JC \& Fei J. Primary. Pollution in Urban Water Supply Network System and Its Control Policy. Beijing: China Architecture \& Building Press, (2006),p.78.

[3] Jiang GX. Urban Water Supply Industry Technology Development Plans for 2000. Beijing: China Architecture \& Building Press, (1993),p.286-287.

[4] Chen Y\&Chen GG. Investigation and Analysis of Water Quality in Shanghai Urban Water Supply Network. China Water \& Wastewater, Vo1.18(2002),p.32-34.

[5] He WH. Investigation and Analysis of Water Quality of Urban Water Supply Network in China. Water \& Wastewater, Vo1.19 (1993),p.15-19.

[6] Appenzeller B.M.R, Batte M., Mathieu L., et al. Effect of Adding Phosphate to Drinking Water on Bacterial Grow in Slightly and Highly Corroded Pipes. Wat. Res., Vo1.35(2001),p.1100-1105.

[7] Langelier W.F.. The Analytical Control of Anti-Corrosion Water Treatment.

American Water Works Association, Vo1. 28(1936),p.1500-1505. 